\title{
Private tutoring at transition points in the English education system: its nature, extent and purpose
}

\author{
Judith Ireson and Katie Rushforth \\ School of Psychology and Human Development \\ Institute of Education, University of London
}

\begin{abstract}
International surveys indicate that the prevalence of private tutoring in England is relatively low but as few national surveys have been undertaken, there is little detailed evidence available. The aim of this research is to provide a systematic description of the nature and extent of private tutoring at three points of transition in the English education system and to explore students' views of the reasons for its use. Over 3000 students completed a questionnaire survey providing information on the extent of private tutoring in school curriculum subjects,reasons for the employment of tutors and demographic information. Over 1100 parents supplied information on their motivation for employing tutors. At the time of the survey, $7.6 \%$ of year 6 pupils were in receipt of tutoring in mathematics, $8.1 \%$ English and $3.2 \%$ science. Comparable figures for year 11 pupils were $7.9 \%$ mathematics, $2.6 \%$ English and $2.8 \%$ science. Overall, $27 \%$ of students reported that they had received tutoring at some stage during their school career and there were clear associations with family socio-economic status and cultural background. Parents employed tutors to increase their child's confidence, improve their understanding of the subject and to help them do well in tests and
\end{abstract}


examinations. Most primary age children indicated that tutors were not needed as their teachers and families provided sufficient educational support. Some families appear to be making strategic use of tutors to help their children make successful transitions in the education system.

\section{Introduction}

Private tutoring has a long established role in learning for many young people in England. In the past, private tutors operated in a largely hidden market as little systematic information was available on the nature and extent of tutoring or the pattern of take up among students from different backgrounds. The aim of this research is to provide a systematic description of the nature, extent and duration of private tutoring at three points of transition in the English education system and to explore students' and parents' views of the reasons for its use.

\section{Conceptual issues}

Although in the past, tutoring was defined as 'one-to-one instruction' (Ellson, 1976) the meaning of the term has expanded considerably to encompass the many different forms of private supplementary tutoring that are to be found around the world (Bray, 2007; Bray \& Kwok, 2003). In addition to tutoring that is provided on a one-to-one basis, private tutors may work with small groups of students, for example in education centres and franchises. Tutoring also takes place in private institutions such as 'juku' in Japan and 'frontisteria' in Greece where students are in large classes or even lecture theatres with video screens to cater for overflows. In these countries, students often attend private classes after completing a day in school. 
Private tutoring may also be carried out at a distance using the mail and telephone, and nowadays tutors use the internet to deliver tutoring on-line. In England, private tutoring usually provides the student with teaching on a one-to-one basis or in small groups (Tanner, Ireson, Day, Rushforth, Tennant, Turcuk and Smith, in press 2009).

Private supplementary tutoring may be distinguished from tutoring that is freely provided in school. A key distinction between these forms of tutoring is that private tutoring is provided for financial gain. Private tutoring may also extend beyond the areas covered by the school curriculum, whereas tutoring that is provided in school is designed to assist learners with the school curriculum, such as literacy and numeracy. For example, in England and New Zealand, one-to-one tuition is provided through the Reading Recovery programme to assist students who make slow progress in the acquisition of basic literacy skills. In England, government policy to increase personalised learning in schools (DfES, 2005) has lead to a number of initiatives to provide extra support that is tailored to the needs of individual students, including one-to-one tuition for pupils aged 7 to 14 who are falling behind. As these forms of tutoring are provided in school they are excluded from existing definitions of private supplementary tutoring, yet they reflect differing traditions, policies and state provision of tutoring and set the context in which private tutors operate in a country.

\section{Nature and extent of tutoring: variations and trends}

International surveys undertaken at the end of the last century such as TIMSS (Beaton, Mullis, Martin, Gonzalex, Kelly \& Smith, 1996) and PISA (OECD, 2001) suggested that the prevalence of private tutoring in Western Europe was relatively low. An analysis of TIMSS data found large differences between countries in the extent of supplementary tutoring in 
mathematics, from less than 5 to over 80 per cent (Baker, Akiba, LeTendre \& Wiseman, 2001). High levels of private tuition were reported in countries such as Columbia, Latvia, Japan, Hong Kong and Korea whereas there was much less in most West European countries. About $10 \%$ of eighth grade students in England had extra lessons in mathematics during the 1994-5 school year, the second lowest proportion in the 41 countries surveyed.

Large differences between countries were also found in the PISA survey undertaken in 2000 (OECD, 2001). This survey covered a wider range of subjects than TIMSS as students were asked about regular attendance at remedial courses in the language of assessment and in other subjects, training to improve study skills or private tutoring. In the UK, 24 per cent of students reported having these forms of support, compared to 71 per cent in Japan and 58 per cent in Korea. Differences in the estimates provided by the PISA and TIMSS surveys may be attributed to the scope of questions, which was wider in the PISA survey than in TIMSS. Neither survey provides sufficiently detailed information to enable comparisons to be made of the extent of tutoring in different subjects. National surveys are required to uncover more detail about the nature and extent of tutoring yet to date very few have been carried out in Western Europe.

\section{Factors affecting the employment of tutors}

Private tutoring appears to be increasing in some parts of the world, including Germany (Mischo and Haag, 2002), Canada (Davies, 2004), and Eastern and Southern Africa (Paviot, Heinsohn, and Korkman, 2008). Reasons vary from one country to another and include school reforms that have introduced standardised curricula coupled with increased testing, which has 
increased parent's anxieties about their children's progress (Davies, 2004); concerns about the quality of state education systems (Bray \& Kwok, 1993; Foondum, 2002; Paviot, Heinsohn, and Korkman, 2008); the extent of stratification and selection in the system (Bray \& Kwok, 1993; Foondum, 2002; Mischo and Haag, 2002) and the extent to which additional lessons are provided free of charge after school as used to be the case in former Soviet bloc countries (Silova, Budiene and Bray, 2006; UNICEF, 1998). Demand for private tutoring may also be affected by the provision of additional support during class time or after school (Ireson, 2004).

Cultural norms and values may also affect the employment of tutors, especially the value placed on education, hard work and self-improvement, which are particularly evident in Asian cultures influenced by the Confucian tradition (Heine, Lehman, Markus and Kitayama, 1999; Salili, 1996; Stevenson \& Stigler, 1992; Wing On, 1996). In contrast, Tweed and Lehman (2002) propose that the USA and other 'culturally Western' groups have been influenced by the Socratic tradition which emphasises the questioning of authority, a tendency to evaluate and self-generated knowledge. England and the USA have also been influenced by a Romantic tradition which sees each individual having 'unique potentialities that emerge in a gentle, nurturing environment' (Eisenberger 1998, p.412).

Although paying for a private tutor is more affordable than private school fees, family financial circumstances may preclude the option of employing a tutor. Tutors are more likely to be employed by parents with higher average incomes and levels of education, who have the resources required to pay tutors' fees (Davies, 2004). This situation has the potential to 
increase social stratification unless governments ensure that sufficient support is given in the state education system.

Private tutors are likely to be employed when students face tests that affect transitions in the education system and act as gateways to higher levels of education and high status occupations. In England there are three main transition points when students face such tests, in year 6 (age 10-11 years) when they prepare to move from primary to secondary school, in year 11 (age 15-16 years) when they prepare to take GCSE examinations at the end of compulsory education and in year 13 (17-18 years) when they sit Advanced level examinations that are the gateway to university courses. This article therefore aims to provide evidence on the nature and extent of tutoring received in these three year groups (year 6, 11 and 13). It examines whether the employment of tutors is affected by students' socioeconomic and cultural background and explores students' and parents' views of the benefits and drawbacks of supplementary tutoring.

\section{Method}

\section{Design of study}

A survey of students in years 6,11 and 13 was undertaken in state maintained primary and secondary schools in England, which were selected from a variety of demographic areas. Researchers administered questionnaires to students in class during the 2003-4 school year, prior to the introduction of government policies to increase individual tuition in schools. Students were given questionnaires to take home for their parents to complete. The research forms part of a wider project that included interviews with parents, however for reasons of 
space only a portion of the data from parent questionnaires is reported here. Further details may be found in Ireson and Rushforth (2005).

\section{Samples}

School samples. When selecting schools to take part in the research, the main aim was to obtain a sample of pupils from a range of socio-economic backgrounds and demographic areas who were attending state maintained schools. A stratified sampling strategy was adopted to select schools from 6 local education authorities (LEAs) in England, two in inner city areas, two in suburban areas and two counties. To ensure that the sample represented a range in terms of socio-economic status, the initial selection of LEAs was based on figures provided by DfES giving percentages of pupils in each LEA eligible for and taking free

school meals. An analysis of these figures revealed that one third of LEAs had less than $11 \%$, one third 11-19\% and one third over 19\%. Based on this categorisation, two LEAs were selected from each level. To ensure that the sample also represented a variety of forms of secondary provision, one LEA in each category was comprehensive and one had some selective secondary schools, such as grammar schools or specialist schools.

Education advisors in the LEAs were contacted for more detailed information about demographic characteristics of their area. They were asked to provide names of primary and secondary schools in affluent, less affluent and more deprived areas. Post-code matching was also used to obtain primary and secondary schools with similar demographic catchments and some secondary schools were asked to supply the names of their main feeder schools. Schools 
were then invited to participate and if they were unable to do so, another school in a similar area was approached.

As the sampling progressed it became clear that insufficient secondary schools would be obtained in the selected LEAs due to a large number of schools being unable to take part in the research. The main reasons given were that the school was already involved in other projects or was under too much pressure. The number of rejections was greatest among LEAs in the city and suburban areas and additional LEAs with similar characteristics were therefore recruited. Information on the percentage of pupils eligible for free school meals, obtained from publicly available information such as school inspection reports. was used to check the composition of the sample.

The final sample comprised 30 primary schools in 9 LEAs and 34 secondary schools and colleges in 10 LEAs. In all, 29 schools contributed to the Year 11 sample and 28 to the Year 13 sample. As some secondary schools did not have sixth forms (years 12 and 13), additional colleges in similar areas were included.

Pupil samples. Samples of 50-60 pupils (two classes) were drawn from each target year group, year 6, year 11 and year 13. In the larger schools, classes were selected on a random basis to be representative of the year group in terms of socio-economic background and attainment. In primary schools with two classes or fewer, all pupils were included. The final 
sample comprised 1254 students in year 6, 1214 in year 11 and 1147 in year 13. Of those who identified their sex $52.2 \%$ were male and $47.8 \%$ female (Table 1 ).

The percentage of pupils who completed questionnaires and were eligible for free school meals was calculated for each year group using pupil level data obtained from DfES. This indicated that the mean percentage eligible for free school meals (14\%) was very close to the national average. Compared with the national averages in 2003 for primary schools (16.8\%) and secondary schools (14.9\%) the achieved secondary sample was close to the national average (12\% in year 11 and $9 \%$ year 13$)$ and the primary sample was somewhat more socially disadvantaged (22\%). When compared with regional figures for primary schools in London (21\%) and the West Midlands (15.7\%), the discrepancy was smaller (Table 1).

\begin{tabular}{lcccccccc}
\hline & \multicolumn{2}{c}{ Year 6 } & \multicolumn{2}{c}{ Year 11 } & \multicolumn{2}{c}{ Year 13 } & \multicolumn{2}{c}{ Total } \\
& $\mathbf{N}$ & $\mathbf{\%}$ & $\mathbf{N}$ & $\mathbf{\%}$ & $\mathbf{N}$ & $\mathbf{\%}$ & $\mathbf{N}$ & \% \\
\hline Male & 487 & 51.6 & 641 & 55 & 397 & 48.8 & 1525 & 52.2 \\
Female & 456 & 48.4 & 524 & 45 & 416 & 51.2 & 1396 & 47.8 \\
Fsm & 208 & 22.1 & 138 & 11.8 & 69 & 8.5 & 2921 & 14.2 \\
\hline
\end{tabular}

Table 1. Sample characteristics

Parent samples. All parents of pupils in the sample were invited to complete a questionnaire. A total of 1170 parent questionnaires were returned, representing $32 \%$ of the original pupil sample. The proportion of returns was higher from parents of year 6 pupils (38\%) than year $11(29 \%)$ and year $13(30 \%)$. Compared to the student sample, the parent sample was slightly biased towards more educated parents in higher occupational categories, however this bias was not great and there was an adequate representation of parents across the range. 


\section{Questionnaires}

The main aim of the student questionnaires was to obtain information on private tuition, however for several reasons the scope of the questions was broadened to cover other sources of educational support. For purposes of statistical classification, pupils were also asked to supply information on their age, ethnic origin and family background. Questionnaires for year 6 pupils covered the same topics as those for older students but were shorter and obtained less detailed information. The parent questionnaires collected information on parents' motivation for employing tutors and their evaluations of tutoring received.

\section{Procedure}

For reasons of confidentiality discussed above, researchers visited the schools to administer the questionnaires so that pupils were reassured that their teachers would not see their answers. Most students completed the survey in their normal classrooms however in some schools they were gathered in the school hall or dinner room. Teachers were handed information about the research and this included a request for them to remain at the periphery of the room and not to help students complete the questionnaires. A researcher explained the research to the whole class and checked that students understood the meaning of 'private tutor' and any other terms they were unclear about. It was also emphasised that teachers would not read the questionnaires and that there were no right or wrong answers. To ensure confidentiality, students were spread out around the room as far as possible and asked to complete their own questionnaire and not discuss their answers with neighbours or look over 
other students' answers. The researcher circulated around the room and answered queries. Year 6 and Year 13 questionnaires were administered during the autumn term and Year 11 towards the end of the spring term or early in the summer term. Year 11 questionnaires were completed in two waves one year apart with 7 schools in the first wave and 22 in the second. Each student was handed an envelope containing a questionnaire to take home for their parents to complete and return to the research team in a freepost envelope. Pupils were advised that if their parents had difficulty with English, they could help by reading the questions to them and recording their answers; a phone number was also provided on the front of each questionnaire for parents to ring if they required help completing the questionnaire.

\section{Results}

Responses to the questionnaires from students in all three year groups were entered into a combined SPSS data base for analysis. The first set of analyses provides information on the subjects for which tutoring was received and the duration of tutoring in years 6,11 and 13 .

\section{Nature, extent and duration of tutoring}

Students were asked if they had a private tutor now or in the past ('ever had' a tutor) and, if so, to indicate the subjects for which they received tutoring and the terms in which tutors had been employed for each subject. The latter information was used to estimate the extent of tutoring at the time of the survey ('tutoring now'). 


\section{Proportion of students with tutors: 'ever had tutoring'}

Of the 3515 students who responded, $27 \%$ indicated that they had received tutoring at some point during their school career (26\% in years 6 and $11,29.5 \%$ in year 13$)$. There were no significant differences between males and females so data from all students were combined for the next analyses.

More students had tutoring in mathematics, followed by English, science and other subjects (Table 2). The percentage of students with tutors for mathematics was very similar in each age group, with $17 \%$ of year $6,18 \%$ year 11 and $19 \%$ year 13 indicating that they had ever had a tutor for this subject. In English, more students reported having a tutor in year $6(16 \%)$ than year $11(10 \%)$ and year $13(8 \%)$. Fewer students had tutoring in science and the figures were similar across the three year groups. A small proportion of year 6 students had tutoring to help them with ability tests such as the $11+$ and verbal and non-verbal reasoning tests. These tests are used by some secondary schools to select the more able students.

In each year group small numbers of students had tutoring in a variety of other subjects. These included art \& design, Spanish, Arabic and PE in year 6, and art \& design, business studies, child development, electronics and food technology in year 11. So although the core curriculum subjects of mathematics, English and science are the ones that attract most private tuition, students receive additional help in a wide range of other subjects (Table 2). 


\begin{tabular}{lccc}
\hline Subject & Year 6 & Year 11 & Year 13 \\
\hline Mathematics & 17 & 18 & 19 \\
English & $16^{\mathrm{a}}$ & 10 & 8 \\
Science & 8 & 6 & 6 \\
Modern languages & 0 & 3 & 3 \\
Humanities & 0 & 2 & 0.4 \\
Entry tests ${ }^{\mathrm{b}}$ & 4 & 0 & 0 \\
Other subjects & 1 & 2 & 2 \\
\hline Total \% & 26 & 26 & 29.5 \\
\hline
\end{tabular}

${ }^{a}$ includes reading and writing

${ }^{\mathrm{b}}$ tests of general ability used in secondary school selection $(11+$, verbal and non-verbal reasoning)

Table 2. Percentage of students with tutors by year group

\section{Proportion of students with tutors: 'tutoring now'}

Students in receipt of tutoring were asked to indicate the school terms in which they had tutoring for each subject. The questionnaire items were phrased slightly differently for the each of the year groups so as to be appropriate for them. Year 6 students were asked when they had tutoring in reading and writing, maths and science and any other subject; Year 11 pupils were asked when they had tutoring in English, mathematics, science, French, history, geography and any other subject; and Year 13 students were asked to list the subjects for which they had received tutoring. Responses to these questions were analysed to provide an estimate of the proportion of students who had tutors during the term in which the questionnaire was completed. Initial exploration of the data found no significant differences in the subjects tutored or the duration of tutoring for males and females. Similarly, there were no significant differences between the white and non-white groups in the subjects tutored or 
the duration of tutoring.

As some students who indicated that they had a tutor at some point in their school career ('ever had' a tutor) did not provide information on the duration of tutoring, the number of students that indicated the terms in which they received tutoring was used as a basis for calculating the percentages of students with a tutor at the time of the survey (have a tutor now). For year 6 , the number of students with tutors in the autumn term was computed and for year 11 , the number of students with tutors in the spring term. A few cases were excluded due to incomplete data, leaving analysis samples of 1165 students in year 6 and 1142 in year 11. In year $6,7.6 \%$ had a tutor for mathematics, $8.1 \%$ for English and $3.2 \%$ science, whereas in year $11,7.9 \%$ had a tutor for mathematics, $2.6 \%$ for English and 2.8\% science (Table 3).

\begin{tabular}{lcccccc}
\hline & \multicolumn{3}{c}{ Year 6 } & & & Year 11 \\
& Maths & English & Science & Maths & English & Science \\
\hline $\begin{array}{l}\text { No of students with } \\
\text { tutor in term }\end{array}$ & 89 & 94 & 37 & 90 & 30 & 32 \\
Valid responses & 1165 & 1165 & 1165 & 1142 & 1142 & 1142 \\
\hline$\%$ with tutor in term & 7.6 & 8.1 & 3.2 & 7.9 & 2.6 & 2.8 \\
\hline
\end{tabular}

Table 3. Percentage of students with tutors in year 6 and year 11 ('tutoring now')

\section{Duration of tutoring}

Year 6 students were asked to give details of tutoring received each term in the previous year whereas older students were asked for details over the past two years. All students were also asked to indicate tutoring received before the period in question: year 6 students were asked 
about tutoring before year 5, year 11 students about tutoring before year 10 and year 13 students about tutoring before year 12. This information was used to provide estimates of the duration of tutoring received in each subject.

Year 6 responses indicated that a common pattern was for one term of tutoring: $44 \%$ maths, $44 \%$ literacy, $45 \%$ science and $47 \%$ other subjects (Table 4). A smaller proportion had tutoring for 2-3 terms, ranging from $16 \%$ maths to $11 \%$ science. A substantial proportion had tutoring before year 5, 28\% in literacy, $27 \%$ maths, $31 \%$ science and $22 \%$ other subjects. The preponderance of a term's duration may be due to the timing of administration during the first term of the final year in primary school.

\begin{tabular}{lcccc}
\hline $\begin{array}{l}\text { Number of terms of } \\
\text { tutoring }\end{array}$ & $\begin{array}{c}\text { Maths } \\
(\mathrm{n}=212)\end{array}$ & $\begin{array}{c}\text { Reading \& } \\
\text { writing } \\
(\mathrm{n}=191)\end{array}$ & $\begin{array}{c}\text { Science } \\
(\mathrm{n}=97)\end{array}$ & $\begin{array}{c}\text { Other } \\
\text { subjects } \\
(\mathrm{n}=101)\end{array}$ \\
\hline 1 & 44 & 44 & 45 & 47 \\
$2-3$ & 16 & 15 & 11 & 19 \\
$4+$ & 12 & 15 & 12 & 13 \\
Before year 5 only & 27 & 28 & 31 & 22 \\
\hline
\end{tabular}

Table 4. Number of terms of tutoring received by year 6 students (percentages).

Year 11 students were more likely than year 6 students to have tutoring over a longer period than one term. In mathematics $29 \%$ and in science $30 \%$ had a tutor for one term, slightly fewer had two or three terms ( $25 \%$ in mathematics and $27 \%$ science) and a smaller number 
had 4 terms or more (15\% and 16\% respectively). Similarly in English, 39\% had tutoring for up to three terms while $13 \%$ had 4 terms or more. A substantial proportion of students had received tutoring before starting their GCSE courses in year 10, ranging from $26 \%$ in French to $56 \%$ in humanities (Table 5).

\begin{tabular}{lccccc} 
Number of terms of & Maths & English & Science & French & Humanities \\
tutoring & $(\mathrm{n}=212)$ & $(\mathrm{n}=114)$ & $(\mathrm{n}=74)$ & $(\mathrm{n}=23)$ & $(\mathrm{n}=25)$ \\
\hline 1 & 29 & 19 & 30 & 30 & 24 \\
$2-3$ & 25 & 20 & 27 & 13 & 20 \\
$4+$ & 15 & 13 & 16 & 31 & 0 \\
before year 10 only & 31 & 50 & 27 & 26 & 56 \\
\hline
\end{tabular}

Table 5. Duration of tutoring received by year 11 students (percentages)

\section{Family background and the prevalence of tutoring}

Relations between the employment of tutors and students' family background were examined using information on socio-economic status and ethnicity. Two indicators of socio-economic status were available: DfES data sets provided individual pupils' eligibility for free school meals and information on parents' education was gathered from the student questionnaires. Of the pupils eligible for free school meals, $19 \%$ had ever had a tutor, as compared with $28 \%$ of pupils who were not eligible $\left(\chi^{2}=15.2, \mathrm{df}=2, \mathrm{p}<.001\right)$. In light of these findings, analysis of variance was used to compare the extent of private tuition in the three year groups, when 
the free school meals indicator was statistically controlled. Free school meals had a significant effect $\left(\mathrm{F}_{1,3}=14.4, \mathrm{p}<.0001\right)$ and there was no significant difference between school years.

Parental education was also strongly associated with private tuition. The overall percentage of students with tutors was $39 \%$ if fathers had been to university, $24 \%$ if fathers had vocational qualifications and $21 \%$ if fathers had only school education, a statistically significant difference $\left(\chi^{2}=73, \mathrm{df}=2, \mathrm{p}<.001\right)$. A similar pattern was found for mother's education but for reasons of space these data are not supplied. The disparity was greatest in year 11 where $43 \%$ of students had received tutoring if their father had a university education, compared to $19 \%$ if fathers had only a school education $\left(\chi^{2}=45.0, \mathrm{df}=4, \mathrm{p}<.001\right)$ (Table 6).

These analyses confirm that parents who have less formal education and are less affluent are least likely to employ tutors for their children. There was a large disparity for the sample of year 11 students who were preparing to take important GCSE examinations at the end of the compulsory phase of education. These examinations are the gateway for progression to Advanced level and thence to university education. 


\begin{tabular}{llcc}
\hline Students' year & Father's & N & Ever had a \\
group & education & & private tutor \% \\
\hline Year 6*** & School & 192 & 18 \\
& College & 204 & 26 \\
& University & 323 & 34 \\
Year 11*** & School & 307 & 19 \\
& College & 255 & 22 \\
& University & 228 & 43 \\
Year 13*** & School & 326 & 26 \\
& College & 290 & 26 \\
& University & 253 & 43 \\
& & &
\end{tabular}

Table 6. Percentage responses to 'Have you ever had a tutor?' by student's year group and father's education.

Relations between the employment of tutors and students' ethnicity were explored through data supplied by student questionnaire responses. About two thirds of the sample was classified as White European and the rate of tutoring ('ever had a tutor') among this group was relatively low (25\%) as compared with most other ethnic groups. Indian students were most likely to have private tuition (45\%), followed by Chinese (35\%), African (31\%), Other Asian (29\%), Pakistani (28\%), Caribbean (27\%) Other White (27\%) and Bangladeshi (20\%). As the numbers in these groups are relatively small, the results should be taken as indicative. 


\section{Motivation for having a tutor}

A list of reasons for having a tutor was compiled from students' answers to open ended questionnaire items during the pilot phase of the research and during the first wave of data collection with year 11 students in 7 schools. This list was presented to students who were asked to tick reasons for having a tutor and to add any other reasons. Responses from students in the first wave were excluded from the analysis presented below. Similarly, the parent questionnaire contained a list of reasons for employing tutors, developed from pilot work, and parents were asked to tick the main reasons for arranging extra tuition for their child.

Most students (71\%) indicated that they had tutors to help them do well in examinations and tests (Table 7). This option was worded slightly differently in the primary and secondary students' questionnaires. Primary students were asked to indicate if they had tutoring to help them pass an exam or entry test for secondary school, while year 11 and year 13 students were asked to indicate if tutoring was to enable them to obtain high grades in examinations. Slightly more year $11(77 \%)$ and year $13(71 \%)$ students than year 6 students $(68 \%)$ had tutors for this reason however the difference was not statistically significant. Some of these students also indicated that the tutor would help them learn subjects more quickly and others indicated that they needed extra help with their work. The percentage of primary school students having tutoring to help them do well in tests and examinations for entry into secondary school was high and supports the suggestion made above that tutoring in literacy and mathematics was to help make a successful transition into the secondary phase of education. 
The second most common reason for having a tutor, given by $40 \%$, was to help students learn subjects more quickly. Fewer year 13 students (27\%) indicated this than year $11(44 \%)$ or year $6(50 \%)\left(\chi^{2}=37.5, \mathrm{df}=2, \mathrm{p}<.001\right)$. This suggests that students taking advanced courses found their work sufficiently challenging.

\begin{tabular}{|c|c|c|c|c|c|}
\hline Students' reasons for having extra tuition & Y6 & Y11 & Y13 & Total & $\chi^{2}$ \\
\hline To do well in an entry exam into secondary & 68 & 77 & 71 & 71 & $4.8 * * *$ \\
\hline \multicolumn{6}{|l|}{ school/high grades in exams } \\
\hline To help me learn subjects quicker & 50 & 44 & 27 & 40 & $37.5^{* * *}$ \\
\hline Because I need extra help with my work & 36 & 31 & 32 & 33 & 1.8 \\
\hline To help me catch up on work missed & 25 & 17 & 11 & 17 & $20.0^{* * *}$ \\
\hline Because I do not learn well from my teachers at & 7 & 17 & 27 & 17 & $46.0^{* * *}$ \\
\hline \multicolumn{6}{|l|}{ school } \\
\hline Because my school does not provide enough help & 7 & 19 & 15 & 13 & $15.6^{* * *}$ \\
\hline The school recommended I got extra help & 16 & 8 & 8 & 11 & $9.9 * *$ \\
\hline Because I have additional learning needs & 11 & 10 & 7 & 9 & 4.2 \\
\hline Total with tutor in year & 297 & 204 & 326 & 827 & \\
\hline
\end{tabular}

$* * \mathrm{p}<.01 * * * \mathrm{p}<.001$

Table 7. Percentage of students with tutors giving reasons for having extra tuition, by year group. 
About one in five students (17\%) had tutors because they did not learn well from their teachers in school, with more year 13 students giving this reason $(27 \%)$ than year $11(17 \%)$ or year $6(7 \%)$, a highly significant difference $\left(\chi^{2}=46, \mathrm{df}=2, \mathrm{p}<.001\right)$. Similarly, year 13 and 11 students were more likely than year 6 students to think that their school did not provide enough help $\left(19 \%, 15 \%\right.$ and $7 \%$ respectively) $\left(\chi^{2}=15.6, \mathrm{df}=2, \mathrm{p}<.001\right)$. It was rarely the only reason for having a tutor. Responses to these questions suggest that primary school students were more satisfied with the help they received from their teachers in school.

About one in ten $(9 \%)$ students had a private tutor because they had additional learning needs and there was little difference between the year groups. It is of interest to note that $11 \%$ of students had tutors on the basis of a recommendation by their school and that such advice was received by more year 6 students $(15 \%)$ than year 11 or $13(8 \%)\left(\chi^{2}=9.9\right.$, df $\left.=2, \mathrm{p}<.01\right)$.

Students gave a number of additional reasons for having a tutor. Tutors were sometimes employed to teach a subject not offered in school, this was mainly for languages such as Spanish, Urdu and Punjabi. A small number of students indicated that there were problems in school such as a timetable clash that prevented them from taking a subject or there was no teacher for that subject. Parents' wishes were also mentioned, as was their inability to offer help themselves.

From the students' perspective the main reason for having a tutor is to help them do well in tests and examinations. Tutors may help students move more quickly through the curriculum, catch up with work missed or assist with additional learning needs, all of which might contribute to doing well in tests and examinations. 


\begin{tabular}{|c|c|c|c|c|c|c|c|c|}
\hline \multirow{2}{*}{ Parents' reasons for arranging extra tuition } & \multicolumn{2}{|c|}{ Year 6} & \multicolumn{2}{|c|}{ Year 11} & \multicolumn{2}{|c|}{ Year 13} & \multicolumn{2}{|c|}{ Total } \\
\hline & $\mathrm{N}$ & $\%$ & $\mathrm{~N}$ & $\%$ & $\mathrm{~N}$ & $\%$ & $\mathrm{~N}$ & $\%$ \\
\hline To improve understanding of the subject* & 56 & 55 & 66 & 84 & 48 & 83 & 170 & 71 \\
\hline To increase self confidence & 68 & 66 & 57 & 72 & 41 & 71 & 166 & 69 \\
\hline To help achieve the highest examination grades ${ }^{* *}$ & 40 & 39 & 59 & 75 & 42 & 72 & 141 & 59 \\
\hline $\begin{array}{l}\text { To help ensure } s / \text { he obtains a place in secondary } \\
\text { school/sixth form or university }\end{array}$ & 44 & 43 & 32 & 41 & 21 & 36 & 97 & 40 \\
\hline To help my child keep up with work in school & 42 & 41 & 31 & 39 & 17 & 29 & 90 & 38 \\
\hline $\begin{array}{l}\text { Because my child does not get enough support } \\
\text { from school }\end{array}$ & 19 & 18 & 20 & 25 & 11 & 19 & 50 & 21 \\
\hline The family is not able to provide enough help & 12 & 12 & 15 & 19 & 11 & 19 & 38 & 16 \\
\hline $\begin{array}{l}\text { Because my child does not learn well from the } \\
\text { teachers in school }\end{array}$ & 14 & 14 & 18 & 23 & 5 & 9 & 37 & 15 \\
\hline It seems the natural thing to do & 19 & 18 & 9 & 11 & 5 & 9 & 33 & 14 \\
\hline To increase the time s/he spends studying & 9 & 9 & 15 & 19 & 6 & 10 & 30 & 13 \\
\hline $\begin{array}{l}\text { I would feel guilty if I did not help my child in this } \\
\text { way }\end{array}$ & 10 & 10 & 10 & 13 & 4 & 7 & 24 & 10 \\
\hline
\end{tabular}

${ }^{*} p<0.01{ }^{* *} p<0.001$

Table 8. Parents' reasons for having extra tuition for their childen, by year group.

Of the 240 parents who employed a tutor and indicated their reasons, $71 \%$ chose 'to improve understanding of the subject' as a reason for seeking extra tuition, this was closely followed by 'to increase self confidence' (68\%), with 'to help achieve the highest examination grades' (59\%) ranked in third place. Although this ranking remained fairly constant for the different year groups, 'To improve understanding of the subject' was given by significantly more year 
11 and 13 parents $(83 \%)$ than year 6 parents $(55 \%)\left(\chi^{2}=23.69, \mathrm{df}=2, \mathrm{p}<0.01\right)$. Similarly 'To help achieve the highest examination grades' was given by $75 \%$ of year 11 parents and $72 \%$ of year 13 parents, compared to $39 \%$ of year 6 parents $\left(\chi^{2}=29.6, \mathrm{df}=2, \mathrm{p}<0.001\right)$. (Table 8$)$.

These results indicate that parents and students perceive private tutoring as a means of improving performance in examinations. In addition, students see tutoring as a way of speeding up their learning, whereas parents emphasise increased confidence and better understanding of the subject.

\section{Preventive factors in the employment of tutors}

To include the perspective of students who did not have tutors, a list of reasons why tutors might not be needed was compiled during the pilot phase of the project and students who indicated that they did not have a tutor were asked to select from this list. As the questionnaire used in the first wave of year 11 data collection had an open question, these responses were excluded from the analysis. The main reasons given were that students felt they could get help from their teacher, members of their family or friends (Table 9). Overall, $64 \%$ of students would go and see a teacher if they needed extra help, with more year $11(68 \%)$ and year 13 $(66 \%)$ than year 6 students $(59 \%)$ giving this reason $\left(\chi^{2}=15, \mathrm{df}=2, \mathrm{p}<.01\right)$. Over half of the students $(56 \%)$ who did not have a tutor felt they received enough help from their family and friends, with significantly more year 6 students giving this reason (77\%) than year $11(52 \%)$ and year $13(38 \%)\left(\chi^{2}=254, \mathrm{df}=2, \mathrm{p}<.001\right)$. These findings indicate that the majority of students do not see a need for additional help as they are able to obtain sufficient support from their teachers or their family and friends. 
Just over a third of students (37\%) indicated that they did not have a tutor because it was too expensive, with more year 13 students (46\%) giving this reason than year 6 or year $11(29 \%$ and $36 \%$ respectively) $\left(\chi^{2}=54.9, \mathrm{df}=2, \mathrm{p}<.001\right)$. Only $8 \%$ thought they would get teased at school if they had a tutor, with more year 6 students giving this reason (14\%), compared to year 11 and year 13 students $(5 \%)\left(\chi^{2}=52.4\right.$, df $\left.=2, \mathrm{p}<.001\right)$.

\begin{tabular}{llllll}
\hline Students' reasons for not having extra tuition & Y6 & Y11 & Y13 & Total & $\chi^{2}$ \\
\hline If I need extra help I will go and see a teacher** & 59 & 68 & 66 & 64 & 15 \\
I get enough help from my family/ friends*** & 77 & 52 & 38 & 56 & 254 \\
I learn enough at school*** & 67 & 49 & 48 & 56 & 78 \\
I don't want a tutor** & 54 & 55 & 57 & 55 & 1.1 \\
I don't need a tutor*** & 53 & 42 & 48 & 48 & 18.5 \\
Tutoring would take up my spare time** & 42 & 46 & 37 & 42 & 11.9 \\
I don't want any extra lessons*** & 50 & 42 & 36 & 43 & 30.8 \\
Tutoring is too expensive*** & 29 & 36 & 46 & 37 & 54.9 \\
Tutoring is a waste of time*** & 25 & 15 & 10 & 17 & 67.7 \\
Tutoring is a waste of money* & 0 & 18 & 14 & 16 & 4.7 \\
I would get teased at school if I had a tutor*** & 14 & 5 & 5 & 8 & 52.4 \\
I would like a private tutor & 6 & 9 & 7 & 7 & 3.6 \\
\hline$\quad *$ p $<.05$ & & & & &
\end{tabular}

Table 9. Percentage of students without tutors giving reasons for not having a tutor, by year group. 
All parents who completed the questionnaire were asked to provide reasons for not employing a private tutor. The most common reason given was 'my child is doing well enough without a tutor' (73\%) and this level of response was similar for children of all age groups. This was followed by 'private tuition is too expensive' $(60 \%)$, 'there is no need as members of the family provide enough help' (57\%) and 'my child does not want extra tuition' (51\%) (Table 10). A substantial proportion of parents (42\%) thought that extra tuition placed too much pressure on children.

The proportion of parents indicating 'private tuition is too expensive' was highest for year 11 students $(67 \%)$ as compared to year $6(60 \%)$ and year $13(52 \%)\left(\chi^{2}=14.59, \mathrm{df}=2, \mathrm{p}<0.01\right)$. Parents of year 13 students were more likely to indicate that 'my child does not want to have extra tuition' $(60 \%)$, as compared with $46 \%$ year 6 and $50 \%$ year $11\left(\chi^{2=} 14.89 . \mathrm{df}=2 \mathrm{p}<0.01\right)$. It would appear that about one third of parents had not considered private tuition as 'It is something I have never thought of doing' was given by $32 \%$ overall and significantly more year 6 parents than year 11 and $13\left(37 \%, 32 \%\right.$ and $24 \%$ respectively) $\left(\chi^{2}=12.96, \mathrm{df}=2\right.$ $\mathrm{p}<0.01)$.

Parental responses supplied some insight into ways in which the family and the school could provide support which was seen to be sufficient to meet their child's needs and thus rendered private tuition unnecessary. Almost two thirds of year 6 parents $(64 \%)$ indicated 'There is no need as members of the family provide enough help', as compared to year $6(51 \%)$ and Year $13(53 \%)\left(\chi^{2}=30.63, \mathrm{df}=2, \mathrm{p}<0.001\right)$. Parents whose children were in year 11 and year 13 were more likely than those in year 6 to indicate that the school provided extra classes $(43 \%$, $39 \%$ and $24 \%$ respectively, $\left.\chi^{2}=30.63, \mathrm{df}=2, \mathrm{p}<0.001\right)$. This indicates that parents perceive 
the family as better able to support children's learning in primary school and that additional classes can reduce the perceived need for private tutoring in secondary school.

\begin{tabular}{|c|c|c|c|c|c|c|c|c|}
\hline \multirow{2}{*}{ Parents' Reasons For Not Having Extra Tuition } & \multicolumn{2}{|c|}{ Year 6} & \multicolumn{2}{|c|}{ Year 11} & \multicolumn{2}{|c|}{ Year 13} & \multicolumn{2}{|c|}{ Total } \\
\hline & $\mathrm{N}$ & $\%$ & $\mathrm{~N}$ & $\%$ & $\mathrm{~N}$ & $\%$ & $\mathrm{~N}$ & $\%$ \\
\hline My child is doing well enough without a tutor & 285 & 72 & 225 & 71 & 236 & 78 & 746 & 73 \\
\hline Private tuition is too expensive ${ }^{*}$ & 237 & 60 & 213 & 67 & 158 & 52 & 608 & 60 \\
\hline $\begin{array}{l}\text { There is no need as members of the family provide } \\
\text { enough help** }\end{array}$ & 256 & 64 & 162 & 51 & 159 & 53 & 577 & 57 \\
\hline My child does not want to have extra tuition* & 181 & 46 & 159 & 50 & 182 & 60 & 522 & 51 \\
\hline Private tuition puts too much pressure on children & 170 & 43 & 132 & 42 & 121 & 40 & 423 & 42 \\
\hline $\begin{array}{l}\text { There is no need as the school provides extra } \\
\text { classes }\end{array}$ & 97 & 24 & 136 & 43 & 118 & 39 & 351 & 35 \\
\hline It is something I have never thought of doing* & 148 & 37 & 100 & 32 & 74 & 24 & 322 & 32 \\
\hline It is too difficult to find a good tutor or class & 98 & 25 & 98 & 31 & 73 & 24 & 269 & 26 \\
\hline It is unfair for some children to have tutors & 76 & 19 & 73 & 23 & 68 & 22 & 217 & 21 \\
\hline $\begin{array}{l}\text { There is no point as people can only achieve } \\
\text { according to their ability }\end{array}$ & 57 & 14 & 55 & 17 & 43 & 14 & 155 & 15 \\
\hline It is too difficult to arrange transport ${ }^{*}$ & 61 & 15 & 38 & 12 & 20 & 7 & 119 & 12 \\
\hline My child is a carer and has no time for extra tuition* & 22 & 6 & 7 & 2 & 4 & 1 & 33 & 3 \\
\hline
\end{tabular}

Table 10. Parents' reasons for not having extra tuition for their children, by year group.

Evidence from parents and their children indicates that support from family, friends and teachers may reduce the demand for tutoring in England. When parents and children feel there is sufficient support at home and at school, they are less likely to perceive a need to seek 
additional help. Parents may become involved in their children's school work through supervising homework or encouraging the child to take part in a variety of educational activities. If they feel unable to provide the help their child needs, perhaps through lack of familiarity with the curriculum or lack of time, they may seek to employ a tutor.

\section{Discussion}

This research aimed to provide estimates of the nature and extent of private tutoring received by primary and secondary school students in England and to examine whether the employment of tutors is affected by students' socio-economic and cultural background. It also explored students' and parents' views of the reasons for having a tutor. It drew on questionnaire responses from primary and secondary school students who were approaching transition points in the English education system when tests and examinations affect progression.

The findings indicate that about a quarter of students receive private tutoring at some stage during their school career. Mathematics is the most popular subject, followed by English and science. Primary school students mainly receive tutoring in literacy and mathematics, with some having tutors to prepare for entrance tests and examinations for selective secondary schools. Mathematics remains the most popular subject for private tuition in secondary school, followed by English, science and modern languages. This may reflect the importance of English, mathematics and science in the national curriculum up to age 16. English and mathematics are especially important, as they are required for progression to higher levels of education after age 16 and also for future employment. It is therefore of interest that there is a greater demand for mathematics than English tutoring among secondary students. This might 
reflect a lack of support in the family, poorer quality of teaching in school or alternatively it may be that the nature of assessments in mathematics makes improving attainment in this subject more amenable to additional coaching.

Parents with higher qualifications were more likely to employ tutors to help their children through the important GCSE examinations that are the gateway to higher education and future careers. This is consistent with research in former socialist countries such as Slovakia, Ukraine and Poland (Silova and Bray, 2006, p.96). Families with a history of participation in higher education are more likely to understand the importance of obtaining good grades in GCSE examinations, which are a requirement for progression to A level and thence to university. Parents who have enjoyed the benefits of higher education themselves are perhaps more likely to hold aspirations for their children to obtain a place at university. As higher qualifications are closely associated with higher occupational status, these parents are more likely to be able to afford the costs associated with employment of private tutors. Private tuition represents a significant economic investment by parents in their children's education but is more affordable and flexible than private school as clients pay only for the additional help they need, a phenomenon that Davies (2004) dubs 'school choice by default'.

For both students and their parents, an important purpose of tutoring was to do well in tests and examinations. This was especially evident in year 11 when students were preparing to take GCSE examinations, but also surfaced in year 6 where there was competition for secondary school places. A small proportion explicitly mentioned the $11+$ and tests of verbal and non-verbal reasoning, and it is also possible that some of the students receiving help in literacy and mathematics were preparing for such tests. Others may have needed to obtain 
good levels in the national Key Stage 2 tests to secure places in popular secondary schools. Recent evidence indicates that preparation for examinations is the main business of many private tuition agencies (Tanner et al, 2009).

Parents invest in private tuition in the expectation that it will improve their children's attainment and many parents and tutors attest to the effectiveness of tutoring. This expectation is supported by some research, however the evidence is limited and findings are mixed. Rushforth and Ireson (2009) found that when students' prior attainment is controlled statistically the effects of private tutoring on attainment in Key Stage tests and GCSE examinations are small and vary between different subjects. Emer (2009) found no significant effects of tutoring on attainment when key variables were statistically controlled. In contrast, experimental studies such as those of Mischo and Haag (2002) and Bloom (1984) found that tutoring raised achievement. Ireson (2004) points to the quality of tutoring as a factor that is likely to influence effectiveness and which deserves greater attention in future research.

Students frequently indicated that a mix of factors contributed to the employment of tutors. Tutors were employed to help students learn faster, to keep up with work or to catch up on work they had missed, perhaps through illness. Older students were more likely to indicate that they did not learn well from their teachers. A small yet significant number had tutoring to help with additional learning needs even though schools have a statutory obligation to provide support, which suggests that in some cases this support was insufficient, leading families to seek extra assistance. 
Parents also indicated a mix of factors that contributed to the employment of tutors, though their ranking differed from that of their children in subtle ways. Parents employed tutors to help their children do well in examinations, especially GCSE and A level, but they ranked improvements in understanding of a subject and increased confidence more highly. For parents of year 6 children, increased confidence was the most important reason for employing a tutor, whereas understanding of the subject was a more important factor for parents of older children. It may be that parents realise the important part played by confidence and understanding in academic achievement, which is in line with psychological research demonstrating reciprocal effects between self concept and achievement at school (Marsh, Byrne and Yeung, 1999). Alternatively it may be that parents are reluctant to acknowledge the competitive advantage they seek for their children through the employment of private tutors.

Many students felt they received sufficient educational support from members of their family and so did not need a tutor. This perhaps reflects the value placed on education by families and their willingness to help their children. Parental support is known to be an influential factor in children's learning and achievement (Desforges and Abouchaar, 2003), particularly in the early years before school. Families continue to be involved when their children go to school, supporting school learning, for example by visits to the library, reading or helping with homework. Private tuition is one of several options that parents may access as they weigh up the demand for extra support and the resources available within the family. Parental involvement in their child's education relates to their perception of the parental role (HooverDempsey and Sandler, 1997) and the employment of tutors may also relate to parents' views about the role of effort and ability in their child's achievement. 
It is of interest to assess whether there has been an increase in the prevalence of tutoring in England given the paucity of surveys to provide comparative data, especially for students in primary school. Our findings suggest that rates of tutoring in England remain relatively low in comparison with other countries. Our estimate of year 11 students who had mathematics tutors during spring term 2004 (7.9\%) is slightly lower than the figure reported for year 8 pupils in 1994-5 based on the analysis of TIMSS data by Baker et al (2001). Also, our estimate of year 11 students who had a mathematics tutor during their school career ('ever had a tutor') was within the range of 16 to 35 percent reported for German students by Mischo \& Haag (2002) and estimates were a little lower than those obtained in the PISA survey (OECD, 2001), which asked about courses in the language of assessment, in other subjects or additional courses outside their school. On the basis of this limited information, we conclude that there has not been a substantial increase in the amount of private tutoring for secondary school students over the last decade in England. Instead it would appear that tutoring has been a hidden aspect of the private education market.

Our findings provide the first evidence on tutoring in year 6 , which shows that $7.6 \%$ of students had tutors for mathematics and $8.1 \%$ for literacy. The lack of research among primary students in the past means that there are no baseline figures for comparison even though it is well known that parents employ tutors to prepare their children for examinations set by selective secondary schools in both the private and state sectors (Bunting and Mooney, 2001). Additional surveys are required to establish whether this market is expanding or not.

The higher rate of tutoring found among non-white ethnic groups as compared with white Europeans was not predicted but is of interest and may reflect perceptions of tutoring in other 
cultures. In South East Asian countries the Confucian tradition encourages an emphasis on self-improvement through hard work (Wing On, 1999; Salili, 1996). In these countries students have a high regard for education, academic achievement is a valued source of pride in the family and the role of effort is seen as central in achieving success. Students are expected to work long hours and frequently attend extra lessons after school (OECD, 2001). Cultural norms and attitudes towards learning among African students have received less attention, yet a recent study indicates that the rate of tutoring in Southern and Central African countries is relatively high, with $46 \%$ of grade 6 pupils receiving private tuition (Paviot, Heinsohn and Korkman 2008). In England, there is a tradition of supplementary tuition for Afro-Caribbean children, mainly through Saturday schools (Stone, 1981). Recent estimates for India indicate that $40 \%$ of students at secondary level attended private tuition (Sujatha, 2007), which is similar to our estimate of the proportion of Indian students in receipt of tuition (45\%) and suggests that cultural norms and attitudes may affect the employment of tutors.

Cultural norms may be overlaid by other factors, such as the perceived need of a child for additional support, the extent to which families feel able to help children themselves and available financial and other resources (Ireson, \& Rushforth, 2005). It may be that ethnic groups differ in the extent to which family members expect to provide educational support to their children themselves. Further research is needed to explore the interplay of different factors among these groups.

As the first survey of its kind in England, this research provides important new information on the nature and extent of private tutoring in primary and secondary schools. Inevitably, it has 
limitations which should be acknowledged. Specifically, samples were selected from a variety of maintained schools and demographic areas but as the schools were located mainly in Southern England and the Midlands, the sample was not representative of the country as a whole. Also, it is important to note that no private schools were included in the study and it proved very difficult to recruit selective state secondary schools (grammar schools) even though several were asked to take part. In future it would be useful to compare the extent of private tutoring provided for students attending different types of school.

By arranging for researchers to administer the questionnaires to students in class we aimed to reduce any concerns students may have about admitting they had a tutor if their teachers could see their responses. Estimates that are obtained from students' self-reports may be unreliable as they rely on memory and accuracy in completing questionnaires and information about current events or in the very recent past is likely to be more reliable than information about events in the more distant past. In future it would be desirable to obtain information from nationally representative samples of students and also from parents who would provide more reliable sources of information on the employment of tutors and the costs of tutoring. Longitudinal studies would also be valuable to provide reliable estimates of changes in the extent of tutoring over time. The estimates provided in this article should provide useful information for establishing a sampling frame for such research.

To conclude, this research indicates that a substantial proportion of students have tutoring at some point during their time at school. Many families provide sufficient educational support for their children especially during the primary phase of education yet some appear to be using private tutors quite strategically to help their children make successful transitions in the 
education system. For many families private tutoring is an affordable and flexible way to help their children, however this inevitably places others at a disadvantage and serves to increase inequality. Until now private tutoring has been a hidden aspect of educational support provided by parents for their children. It is important to monitor the impact of this form of private education in the UK and also in other European countries in future.

\section{Acknowledgements}

The research was supported by grant RES-000-23-0117 from the Economic and Social Research Council. The authors would like to acknowledge the assistance provided by all the participating schools and to thank all the students and parents for providing information.

\section{References}

Baker, D. P., Akiba, M., Letendre, G. \& Wiseman, A. W. (2001) Worldwide shadow education: outside-school learning, institutional quality of schooling and cross-national mathematics achievement. Educational Evaluation and Policy Analysis, 23, 1, 1-17.

Beaton, A., Mullis, I., Martin, M., Gonzalez, E., Kelly, D. \& Smith, T. (1996) Mathematics achievement in the middle school years: IEA's Third International Mathematics and Science Study. Boston College: Center for the Study of Testing, Evaluation and Educational Policy.

Bloom, B. S. (1984) The 2 sigma problem: the search for methods of group instruction as effective as one-to-one tutoring. Educational Leadership, May, 4-17. Bray, M. (2006) 
Private supplementary tutoring: comparative perspectives on patterns and implications. Compare 36, 4, 515-530.

Bray, M. (2007) The shadow education system: Private tutoring and its implications for planners (second edition). Paris: UNESCO: International Institute for Educational Planning.

Bray, M. \& Kwok, P. (2003) Demand for private supplementary tutoring: conceptual considerations and socio-economic patterns in Hong Kong. Economics of Education Review 22, 6, 611-620.

Bunting, B. P. \& Mooney, E. (2001) The effects of practice and coaching on test results for educational selection at eleven years of age. Educational Psychology, 21, 3, 243-253.

Davies, S. (2004) School choice by default? Understanding the demand for private tutoring in Canada, American Journal of Education, 110(3), 233-255.

Desforges, C. with Abouchaar, A. (2003) The impact of parental involvement, parental support and family education on pupil achievement and adjustment: A review of the literature. Research Report 433, London: Department for Education and Skills.

DfES (2005) Higher Standards, Better Schools For All. UK Government White Paper. London: HMSO.

Eisenberger, R. (1998) Achievement:the importance of industriousness. Behavioural and Brain Sciences, 21, 3, 412-413.

Ellson, D. G. (1976) Tutoring, In Gage, N. (Ed.) The Psychology of Teaching Methods. Chicago: The University of Chicago Press.

Foondum, A. R. (2002) The issue of private tuition: an analysis of the practice in Mauritius and selected South-East Asian countries. International Review of Education, 48 (6), 485575. 
Heine, S. J., Lehman, D. R., Markus, H. R. \& Kitayama, S. (1999) Is there a universal need for positive self-regard? Psychological Review, 106, 766-794.

Hoover-Dempsey, K.V. \& Sandler, H. M. (1997) Why do parents become involved in their children's education? Review of Education Research, 67, 3, 2-42.

Ireson, J. (2004) Private tutoring: how prevalent and effective is it? London Review of Education, 2, 2, 109-122.

Ireson, J. \& Rushforth, K. (2005) Mapping and Evaluating Shadow Education. Final Report to the Economic and Social Research Council.

Marsh, H. W., Byrne, B. M. \& Yeung, A. S. (1999). Causal ordering of academic self-concept and achievement: Reanalysis of a pioneering study and revised recommendations.

Educational Psychologist, 34, 154-157.Mischo, C. \& Haag, L. (2002) Expansion and Effectiveness of Private Tutoring, European Journal of Psychology of Education, Vol. XVII, No. 3, pp. 263-273.

OECD (2001) Knowledge and Skills for Life: First Results from the OECD Programme for International Student Assessment (PISA) 2000. Paris: OECD Publications.

Paviot, L., Heinsohn, N. and Korkman, J. (2008) Extra tuition in Southern and Eastern Africa: Coverage, growth, and linkages with pupil achievement. International Journal of Educational Development, 28, 149-160.

Rushforth, K. \& Ireson, J. (2009) The Quality and Effectiveness of Private Tuition. Paper presented at the British Educational Research Association Annual Conference, Manchester, 2-5 September 2009.

Salili, F. (1996) Accepting personal responsibility for learning, in D. A. Watkins and J. B. Biggs (Eds.) The Chinese Learner: cultural, psychological and contextual influences. 
Hong Kong, Comparative Education Research Centre, The University of Hong Kong, 85105.

Silova, I. \& Bray, M. (2006) The hidden marketplace: Private tuition in former socialist countries in ESP (Eds.) Education in a Hidden Marketplace: Monitoring of Private Tutoring, Budapest: Education Support Program (ESP) of the Open Society Institute. Silova, I., Budiene, V. and Bray, M. (2006) The hidden marketplace: private tutoring in former socialist countries in ESP (Eds.) Education in a Hidden Marketplace: Monitoring of Private Tutoring, Budapest: Education Support Program (ESP) of the Open Society Institute.

Smyth, E. (2008) The more, the better? Intensity of involvement in private tuition and examination performance. Educational Research and Evaluation, 14, 5, 465-476.

Stevenson, H. \& Stigler, J. (1992) The Learning Gap. New York: Summit Books.

Stone, M. (1981) The Education of the Black Child. The Myth of Multiracial Education, London: Fontana.

Sujatha, K. (2007) Private tuition in India: trends and policy implications. Paper presented at IIEP Policy Forum 'Confronting the Shadow Education System: What Government Policies for What Private Tutoring?' Paris, 5-6 July, 2007

Tanner, E., Ireson, J., Day, N., Rushforth, K., Tennant, R., Turcuk, O. and Smith, K. (2009) Private Tuition in England. Research Report DCSF-RR081, London: Department for Children, Schools and Families.

Tweed, R. G. \& Lehman, D. R. (2002) Learning considered within a cultural context: Confucian and Socratic approaches. American Psychologist,57, 2, 89-99.

UNICEF (1998) Education For All? The MONEE project Regional Monitoring Report No. 5, No 5. Florence: UNICEF Child Development Centre. 
Wing On, L. (1996) The cultural context for Chinese Learners: conceptions of learning in the Confucian tradition, in D. A. Watkins and J. B. Biggs (Eds.) The Chinese Learner: cultural, psychological and contextual influences. Hong Kong, Comparative Education Research Centre, The University of Hong Kong, 25-41. 